\title{
A Simple Technique for Assaying Certain Microbial Phytotoxins and its Application to the Study of Toxins Produced by Spiroplasma citri
}

\author{
By M. J. DANIELS \\ John Innes Institute, Colney Lane, Norwich NR4 $7 U H$
}

(Received 27 December 1978)

\begin{abstract}
A method for detecting and assaying phytotoxins has been developed which depends on damage caused by toxins to cells in leaves of broad bean plants and the consequent production of black polyphenol oxidation products. The assay, which has the advantage of being relatively unaffected by components of complex microbial growth media, has been used to study the properties of a toxin produced by the plant-pathogenic mycoplasma Spiroplasma citri. The toxin is an unstable, acidic, polar compound of low molecular weight.
\end{abstract}

\section{INTRODUCTION}

The plant-pathogenic mycoplasma Spiroplasma citri is the causal agent of citrus stubborn (or little-leaf) disease (Markham et al., 1974; Rana et al., 1975). Infection by S. citri of certain herbaceous hosts, e.g. Madagascar periwinkle (Catharanthus roseus) or broad bean (Vicia faba), results in the development of severe disease symptoms including stunting, foliar chlorosis, wilting and death (Markham \& Townsend, 1974). Daniels \& Meddins (1974) suggested that a translocatable toxin produced by spiroplasmas in the plant is responsible, at least in part, for the symptoms, and preliminary evidence was obtained for the presence of phytotoxic material in $S$. citri cultures.

Early stages of investigation of biologically active substances produced in cultures of micro-organisms invariably demand the use of a bioassay to monitor purification procedures and to study general properties. Unfortunately bioassays are rarely satisfactory for use with crude preparations because the response of the test organisms to the active substance is often drastically affected by other components of the mixture. The culture medium used for $S$. citri has a high osmotic pressure (about $15 \mathrm{~atm}$ ) and the broth components are toxic to plant tissues so that in many bioassays which have been used for toxins produced by plant pathogens (e.g. inhibition of root growth, induction of permeability changes, wilting or chlorosis), the effect of active metabolites is obscured by non-specific damage caused by the culture medium (M. J. Daniels, unpublished observations).

I noticed that drops of $S$. citri culture fluid (but not uninoculated growth medium) placed on the leaves of broad bean plants rapidly caused tissue necrosis followed by blackening due to polyphenoloxidase action. From this observation the assay technique described in this paper was developed. The assay has the merit of being applicable to unfractionated culture fluids and is therefore useful in the early stages of purification and for surveying large numbers of strains for toxin production. The application of the assay is illustrated by experiments to study the properties of $S$. citri toxin, although the procedure may be useful for phytotoxins produced by other organisms, e.g. Pseudomonas syringae. 


\section{METHODS}

Organisms. Spiroplasma citri strains were isolated from seed coats of aborted seeds in mis-shapen fruits collected from little-leaf diseased trees in Israel (Daniels et al., 1973), except for the Moroccan (R8-A2) and Californian (C189) strains which were provided by Dr P. Saglio. Unless otherwise stated, strain SP-A (NCPPB 2565) was used. Spiroplasmas were grown at $32{ }^{\circ} \mathrm{C}$ in $\mathrm{T}$ medium, which contained PPLO broth (Difco; $\left.21 \mathrm{~g}^{-1}\right)$, sorbitol $\left(70 \mathrm{~g} \mathrm{l}^{-1}\right)$, glucose $\left(1 \mathrm{~g} \mathrm{l}^{-1}\right)$, fructose $\left(1 \mathrm{~g} \mathrm{l}^{-1}\right)$, phenol red $\left(20 \mathrm{mg} \mathrm{l}^{-1}\right)$ and horse serum (Wellcome no. 3 or Gibco-Biocult, mycoplasma-screened, 10\%, v/v). T medium was also used for Acholeplasma laidlawii PG8, and for three mycoplasmas cultured from diseased plants (Giannotti, 1974) 'Eggplant proliferation' and 'Stolbur C' (both serologically related to the bovine mycoplasma PG 50) and 'Phyllody 1' (related to $A$. laidlawii) - which were obtained from Dr J. Giannotti. The corn stunt spiroplasma strain B was provided by Dr R. F. Whitcomb, and was grown at $30^{\circ} \mathrm{C}$ in medium M1 (Williamson \& Whitcomb, 1975) or in the simplified medium of Markham et al. (1977).

Cultures of Pseudomonas syringae and Ps. caryophylli were obtained from Dr M. Gasson, and were grown at $20^{\circ} \mathrm{C}$ with shaking in a medium containing $\mathrm{NH}_{4} \mathrm{H}_{2} \mathrm{PO}_{4}\left(1 \mathrm{~g} \mathrm{l}^{-1}\right), \mathrm{KCl}\left(0 \cdot 2 \mathrm{~g} \mathrm{l}^{-1}\right), \mathrm{MgSO}_{4} \cdot 7 \mathrm{H}_{2} \mathrm{O}$ $\left(0 \cdot 2 \mathrm{~g}^{-1}\right)$ and glucose $\left(2 \mathrm{~g}^{-1}\right)$, adjusted to $\mathrm{pH} 7 \cdot 0$ with $\mathrm{NaOH}$.

Vicia faba cv. 'The Midget' (Suttons Seeds, Torquay, Devon) was grown in a glasshouse at $20^{\circ} \mathrm{C}$ in $9 \mathrm{~cm}$ pots of soil-less compost. During winter, supplementary lighting from sodium vapour lamps was provided for $16 \mathrm{~h}$ each day. Plants were ready for use 4 to 6 weeks after sowing.

Toxin assay. Detached young leaves were surface-sterilized by immersion for $30 \mathrm{~s}$ in $70 \%(\mathrm{v} / \mathrm{v})$ ethanol followed by thorough washing with sterile water. Subsequent operations were performed aseptically in a laminar-flow sterile cabinet (John Bass, Crawley). The leaves were placed upside down on filter paper moistened with sterile water and the lower epidermis was stripped away using fine-pointed tweezers. The stripped leaves were cut into pieces about $3 \mathrm{~mm}$ square with a new scalpel blade and the tissue pieces were floated (stripped surface down) on $2 \%(\mathrm{w} / \mathrm{v})$ sorbitol solution until required. The material could be stored at room temperature for at least $6 \mathrm{~h}$ without loss of activity.

Suitable dilutions of solutions to be tested were dispensed in $0.2 \mathrm{ml}$ portions in $2 \mathrm{ml}$ screw-capped vials (Flow Laboratories, Irvine, Scotland) or in wells in plastic haemagglutination plates. Pieces of leaf tissue were blotted gently with filter paper and floated, stripped surface down, on the solutions, about five pieces being added to each vial or well. Plastic plates were sealed with tape to prevent evaporation. After incubation overnight at $37^{\circ} \mathrm{C}$ leaf pieces were washed briefly in water and extracted twice with methanol for $30 \mathrm{~min}$ at room temperature to fix the tissue and remove chlorophyll. The degree of blackening of each leaf piece was assessed visually on a scale 0 (no blackening) to 4 (whole area black).

Polyphenoloxidase preparation and assay. Procedures similar to those described by Kenten (1958) were used. Broad bean leaves $(14 \mathrm{~g})$ were chopped with scissors and ground with $14 \mathrm{ml}$ water at $4{ }^{\circ} \mathrm{C}$. Debris was filtered off with muslin and the filtrate was centrifuged for $20 \mathrm{~min}$ at $12000 \mathrm{~g}$. The supernatant solution was dialysed for $24 \mathrm{~h}$ at $4{ }^{\circ} \mathrm{C}$ against 51 buffer prepared by mixing 4 mu-citric acid and 4 mM- $\mathrm{Na}_{2} \mathrm{HPO}_{4}$ at $\mathrm{pH}$ 5.5. After dialysis the extract was twice frozen and thawed and the precipitate was removed by centrifuging at $2{ }^{\circ} \mathrm{C}$ for $30 \mathrm{~min}$ at $20000 \mathrm{~g}$. The solution was finally stored in small portions at $-20^{\circ} \mathrm{C}$ until required. Complete assay mixtures contained; citric acid/sodium citrate buffer $(25 \mathrm{~mm}, \mathrm{pH} 6.0), 0.5 \mathrm{ml}$; catechol $\left(10 \mathrm{mg} \mathrm{ml}^{-1}\right), 0.1 \mathrm{ml}$; sodium dodecyl sulphate $(20 \mathrm{~mm}), 0.1 \mathrm{ml}$; enzyme extract, $0.2 \mathrm{ml}$; and water, $0.3 \mathrm{ml}$. After incubation at $20^{\circ} \mathrm{C}$ for suitable periods the coloured oxidation product was measured by absorbance at $400 \mathrm{~nm}$, using a Unicam SP1700 spectrophotometer.

\section{RESULTS AND DISCUSSION}

\section{The assay}

Pieces of broad bean leaf tissue floated on $S$. citri culture fluids (either whole cultures or medium from which the spiroplasmas had been removed by centrifuging at $8000 \mathrm{~g}$ for 20 min) turned black after incubation overnight at $37^{\circ} \mathrm{C}$. However, tissue floated on water or on uninoculated $\mathrm{T}$ medium (adjusted to the same $\mathrm{pH}$ value as the spiroplasma culture with lactic acid), or on cultures of the corn stunt spiroplasma, A. laidlawii or mycoplasmas isolated from plants ('Eggplant proliferation', 'Stolbur C' and 'Phyllody 1') failed to show blackening. By diluting the culture medium with water and noting the dilution at which the tissue failed to turn black it was possible to use the phenomenon as a quantitative assay (Fig. 1).

The youngest leaves (preferably not fully expanded) were found to be the most sensitive, 


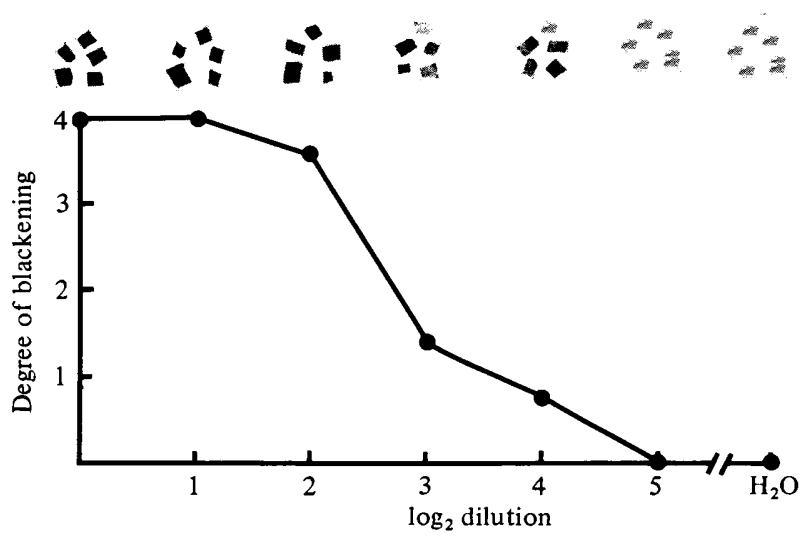

Fig. 1. Appearance of pieces of bean leaf tissue after incubation with a range of dilutions of $S$. citri culture filtrate and with water (top). The average degree of blackening for each dilution was assessed as described in Methods to give the dose-response curve.

to the extent that the dilution end-point for a given $S$. citri culture could be ten times lower for the youngest leaves than for the oldest leaves on a plant. Nevertheless, comparable leaves from different plants gave very similar results.

Leaf tissue taken from plants grown under sub-optimal conditions (e.g. under lower light intensity in winter) sometimes showed blackening when floated on water. This could be prevented by incorporating not less than $2 \%(\mathrm{w} / \mathrm{v})$ sorbitol in the water, and by diluting samples for assay with $2 \%$ sorbitol solution rather than with water.

For optimum blackening it was necessary to adjust test solutions to an acid $\mathrm{pH}$ value, about 5.0 being most suitable. An advantage was that growth of any contaminating bacteria was discouraged under these conditions. It must be pointed out, however, that tissue floated on control solutions which were inadvertantly contaminated seldom turned black, supporting the hypothesis that blackening is induced by an agent restricted to $S$. citri cultures. Culture filtrates of all $S$. citri strains tested (SP-A, SP-4, SP-5, SP-6, SP-12, SP-13, SP-14, SP-17, ASP-1, ASP-3, ASP-6, ASP-15, ASP-24, R8-A2 and C189) and of the two plantpathogenic bacteria, Pseudomonas syringae and Ps. caryophylli, gave the blackening reaction.

The blackening which followed treatment of leaf tissue with culture preparations depended on both enzyme (polyphenoloxidase) and substrate (polyphenols) being present in the tissue. The reaction could be speeded up considerably by including additional substrate in the incubation mixture. When catechol $\left(1 \mathrm{mg} \mathrm{ml}^{-1}\right)$ was added, blackening was observed after only 4 to $5 \mathrm{~h}$ at $37^{\circ} \mathrm{C}$. End-points of dilution assays were the same whether or not ca techol was added.

It was necessary for leaf tissue to be in contact with culture preparations for about $4 \mathrm{~h}$ before sufficient cell damage occurred to cause blackening. If, after $4 \mathrm{~h}$, tissue was removed from the culture solution, rinsed and incubated in $2 \%$ sorbitol solution, complete blackening was noted after a further $12 \mathrm{~h}$.

Bean leaves contain latent polyphenoloxidase which is activated by certain surface-active agents which denature proteins (Kenten, 1958). Experiments using a partially purified cellfree extract of leaves showed that butanol extracts of $S$. citri cultures (which possessed toxin activity) contained neither polyphenol substrates nor activators of the latent enzyme (Table 1) which could account for their ability to induce blackening of tissue. It is probable that the phenomenon results from disruption of cells and organelles by a toxin in $S$. citri cultures, followed by activation of the latent polyphenoloxidase by enzymes or other destructive agents released from damaged cell compartments.

The effect of culture preparations could be simulated by floating leaf tissue on detergent 
Table 1. Effect of spiroplasma metabolites on the activity of partially purified polyphenoloxidase preparations from broad bean leaves

$\begin{array}{ll}\text { Incubation mixture } & A_{\mathbf{4 0 0}} \dagger \\ \text { Complete assay mixture* } & 1 \cdot 58 \\ \text { - substrate (catechol) } & 0 \\ \text { - substrate + butanol extract of uninoculated medium } & 0 \\ \text { - substrate + butanol extract of } S \text {. citri culture } & 0 \\ \text { - activator (sodium dodecyl sulphate) } & 0 \cdot 10 \\ \text { - activator + butanol extract of uninoculated medium } & 0 \cdot 06 \\ \text { - activator + butanol extract of } S \text {. citri culture } & 0 \cdot 07\end{array}$

* See Methods.

$\dagger$ Absorbance values are corrected for appropriate blank readings. Replicates differed by less than $5 \%$.

solutions (e.g. sodium dodecyl sulphate at concentrations above $0.001 \%, w / v)$ and, as noted above, cell damage caused by osmotic shock similarly resulted in tissue blackening.

\section{Properties of the toxic substance present in S. citri culture}

Portions of $S$. citri culture and of uninoculated $\mathrm{T}$ medium were adjusted to $\mathrm{pH}$ values of $3 \cdot 0,7 \cdot 0$ and $9 \cdot 6$, using either $1 \mathrm{M}-\mathrm{HCl}$ or $1 \mathrm{M}-\mathrm{NaOH}$, and extracted by shaking for $1 \mathrm{~min}$ with 1 vol. water-saturated 1-butanol, diethyl ether or chloroform. The phases were separated by centrifuging and the organic layers were removed and evaporated to dryness under reduced pressure at a temperature not exceeding $45^{\circ} \mathrm{C}$. Solids were dissolved in water, the $\mathrm{pH}$ was adjusted to 5.0 and the solution was assayed for activity with bean leaves. Ether and chloroform failed to extract the toxic activity, but butanol extracts obtained at all three $\mathrm{pH}$ values possessed activity. A single extraction with 1 vol. butanol recovered up to $50 \%$ of the activity. Extracts of uninoculated medium had no leaf-blackening activity, unless added to assay mixtures at concentrations equivalent to four to five times those present in the medium.

Further $10 \mathrm{ml}$ portions of culture were adjusted to $\mathrm{pH} \mathrm{2,5,7}$ and 9 and passed slowly through $3 \mathrm{ml}$ beds of Zerolit $225\left(\mathrm{Na}^{+}\right)$and Zerolit FFIP $\left(\mathrm{Cl}^{-}\right)$resins. The effluent solutions were adjusted to pH 5 and tested for activity. After passage through the cation-exchange resin (Zerolit 225) the solution retained full activity, but the anion-exchange resin completely removed activity from the solution at $\mathrm{pH} 5,7$ or 9 and partially removed activity at $\mathrm{pH} 2$. DEAE-cellulose was also effective in removing the toxic activity. When acidified cultures were shaken with charcoal the active material was adsorbed, but could be recovered by shaking the charcoal with ethanol containing $1 \%$ (v/v) ammonia solution (sp.gr. 0.880). The activity was not removed from acidified cultures by steam distillation or by prolonged vacuum distillation of lyophilized culture fluids. When butanol extracts of $S$. citri cultures (dissolved in water) were applied to columns of Sephadex G-10 eluted with distilled water, all the toxic activity eluted with low molecular weight substances, detected by conductivity (salts present in the extract) or radioactivity (derived from $\left[{ }^{14} \mathrm{C}\right]$ glucose mixed with the sample). No activity was recovered in the void volume [indicated by Blue Dextran 2000 (Pharmacia) mixed with the sample].

These properties indicate that the toxicity to bean leaves is due to a polar, acidic substance of molecular weight probably not more than 200 to 300 . The principal acidic metabolite of $S$. citri has been reported to be $\mathrm{L}(+)$-lactic acid formed by fermentation of glucose and fructose, reaching a concentration of about $6 \mathrm{~mm}$ (Hawthorne \& Vandemark, 1977). Our own estimations of lactate concentrations in cultures, obtained by chemical and enzymic methods described by Dawes et al. (1971), or by titrating T medium with lactic acid to the final $\mathrm{pH}$ value reached by cultures (about $\mathrm{pH} 5.0$ ) gave very similar values.

The toxicity of lactate to bean leaves was tested by floating pieces of tissue on solutions adjusted to $\mathrm{pH} 5$ with $\mathrm{NaOH}$. Some blackening was observed, but only at concentrations 
higher than $30 \mathrm{~mm}$. A range of anionic buffers (acetate, citrate, citrate/phosphate, maleate, phosphate and succinate) was tested at $10 \mathrm{~mm}, \mathrm{pH} 5$ or 6 , and found to be non-toxic.

Many attempts were made to purify the toxin, based on the properties deduced above, but all attempts were frustrated due to the instability of the material. Butanol extraction was a useful first stage, since a single extraction step recovered up to half the toxin activity but only about $4 \%(\mathrm{w} / \mathrm{w})$ of the total solutes in culture fluids. Fractionation of the extracts by gel filtration through Sephadex G-25 or G-10 failed to separate the toxin from other low molecular weight substances, and anion-exchange separations on Dowex 1, Zerolit FF or DEAE-cellulose gave inconsistent results, probably caused by inactivation of the toxin. It was usually impossible to recover active material from paper or thin layers after chromatography or electrophoresis in a variety of solvents and buffer systems. Although the toxin seemed to be stable in cultures, partially purified preparations (e.g. butanol extracts) rapidly lost activity on storage at $4{ }^{\circ} \mathrm{C}$ or $-20^{\circ} \mathrm{C}$.

Attempts were also made to detect any substances which could be the toxin by comparing gas-liquid chromatograms of spiroplasma culture preparations with similar preparations of uninoculated media. A range of derivatives thought suitable for a polar, acidic compound were prepared (i.e. propyl, methyl, acetyl, heptafluorobutyryl and trimethylsilyl derivatives) and analysed, but no unique peaks were observed in preparations from cultures compared with those from uninoculated growth media. Quantitative variations were, however, apparent, notably in peaks corresponding to derivatives of lactic acid, which were always much higher in cultures. The complex spiroplasma growth medium gave chromatograms containing many peaks, so it is possible that small peaks due to the toxin might have been obscured. Alternatively, the toxin could be present in amounts too small to be detected (i.e. it could be a highly active compound), or it may not have been rendered sufficiently volatile for gas chromatography by any of the derivatization procedures.

Unlike the low molecular weight, neutral toxic substance produced by $S$. citri (Daniels \& Meddins, 1974), the acidic toxin had little activity against algae, yeasts and fungi, but it inhibited the germination of seeds of a range of plants tested (Daniels \& Niven, 1978). Indeed, inhibition of seed germination could be used as an alternative assay for semipurified toxin preparations with the merit that it could be used for testing the sensitivity of a wide range of plants. However, for crude culture preparations the bean leaf assay described in this paper remains the only satisfactory method which we have yet found, and our observations that it can be applied to the detection of toxins in cultures of pathogenic pseudomonads suggests that it may be widely applicable to the study of toxins which disrupt plant cells.

My thanks are extended to Miss S. Field, Mrs C. Barnes and Miss J. Longland for assistance with part of the work described.

\section{REFERENCES}

Daniels, M. J. \& Meddins, B. M. (1974). The pathogenicity of Spiroplasma citri. Les Colloques de l'Institut National de la Santé et de la Recherche Médicale 33, 195-200.

Daniels, M. J. \& Niven, C. F. (1978). Sensitivity of plants to Spiroplasma citri toxins. Sixty-eighth Annual Report, John Innes Institute, p. 105.

Daniels, M. J., Markham, P. G., Meddins, B. M., Plaskitt, A. K., Townsend, R. \& Bar-Joseph, M. (1973). Axenic culture of a plant pathogenic spiroplasma. Nature, London 244, 523-524.
Dawes, E. A., MCGill, D. J. \& Midgley, M. (1971). Analysis of fermentation products. Methods in Microbiology 6A, 53-215.

GiannotTI, J. (1974). Cultures de mollicutes à partir de plantes atteintes de jaunisse et d'insectes vecteurs. Les Colloques de l'Institut National de la Santé et de la Recherche Médicale 33, 99-106.

HAWTHORNe, J. D. \& VANDEMARK, P. J. (1977). Metabolic studies of Spiroplasma citri. Abstracts of the Annual Meeting of the American Society for Microbiology, 133. 
KENTEN, R. H. (1958). Latent phenolase in extracts of broad bean (Vicia faba L.). Biochemical Journal 68, 244-251.

Markham, P. G. \& Townsend, R. (1974). Transmission of Spiroplasma citri to plants. Les Colloques de l'Institut National de la Santé et de la Recherche Médicale 33, 201-206.

Markham, P. G., TownSEND, R., BAR-Joseph, M., Daniels, M. J., Plaskitt, A. \& Meddins, B. M. (1974). Spiroplasmas are the causal agents of citrus little-leaf disease. Annals of Applied Biology 78, 49-57.
Markham, P. G., Townsend, R., Plaskitt, K. \& SAGLIO, P. (1977). Transmission of corn stunt to dicotyledonous plants. Plant Disease Reporter 61, 342-345.

Rana, G. L., Kaloostian, G. H., Oldfield, G. N., Granett, A. L., Calavan, E. C., Pierce, H. D., LeE, I. M. \& GumpF, D. J. (1975). Acquisition of Spiroplasma citri through membranes by homopterous insects. Phytopathology 65, 1143-1145.

Williamson, D. L. \& Whitcoms, R. F. (1975). Plant mycoplasmas: a cultivable spiroplasma causes corn stunt disease. Science 188, 1018-1020. 